\title{
DAMPAK PELAKSANAAN PROGRAM SEKOLAH LIMA HARI TERHADAP LEMBAGA PENDIDIKAN ISLAM DI KOTA SALATIGA
}

\section{THE EFFECTS OF THE FIVE DAYS SCHOOLING PROGRAM TOWARDS ISLAMIC EDUCATION INSTITUTION IN SALATIGA}

\author{
Siti Muawanah \\ Balai Penelitian dan Pengembangan Agama Semarang \\ Jl. Untung Suropati Kav. 70 Bambankerep Ngaliyan Semarang \\ Email: analitbang@gmail.com
}

Naskah diterima tanggal 2 Februari 2018. Naskah direvisi tanggal 20 Februari 2018. Naskah disetujui tanggal 18 Mei 2018

\begin{abstract}
Abstrak
Program Sekolah Lima Hari (PS5H) merupakan program yang menuai pro dan kontra. Puncaknya saat Mendikbud RI mengeluarkan Permendikbud Nomor 23 Tahun 2017 tentang Hari Sekolah. Di Jawa Tengah pro kontra program lima hari sekolah sudah lebih awal terjadi, yaitu sejak muncul SE Gubernur Jateng Nomor 420/006752/2015 yang kemudian ditindakanjuti dengan SK Kepala Dinas Pendidikan Provinsi Jawa Tengah Nomor 420/03737. Salah satu wilayah yang mengikuti SE tersebut adalah Kota Salatiga. Tulisan ini bermaksud menggambarkan pelaksanaan PS5H di Kota Salatiga dan dampaknya terhadap pendidikan Islam. Dengan menggunakan pendekatan kualitatif, penelitian ini menemukan tiga hal. Pertama, pelaksanaan PS5H tidak menggunakan model 11 sebagaimana diatur pasal 6 SK Kepala Dinas Pendidikan Provinsi Jawa Tengah Nomor 420/03737. Kedua, PS5H berdampak tidak langsung terhadap lembaga pendidikan keagamaan Islam. Ketiga, program tersebut berdampak langsung secara fisik, psikis, dan ekonomis. Bahkan, secara sosiologis, program yang salah satu tujuannya untuk mendekatkan hubungan orang tua dan anak ini justru dalam kenyataanya tidak tercapai karena anak lebih memilih main bersama teman-temannya maupun masih sibuk ke sekolah untuk mengikuti kegiatan ekstrakurikuler. Dengan demikian, program sekolah lima hari dalam praktiknya hampir tidak beda dengan program sekolah enam hari.
\end{abstract}

Kata kunci: Sekolah lima hari, pendidikan keagamaan Islam, Kota Salatiga, dampak

\begin{abstract}
The Five Days Schooling Program which refers to the circular of the Governor of Central Java No. $420 / 006752 / 2015$ is a controversial issue in Central Java. This circular asked schools in Central Java to apply five schooling days. Kota Salatiga is a regency that answers the decree by applying the program in 20 schools. Unfortunately, the implementation of the program is not the same as the model mentioned in the Decree of provincial of education in Central Java No. 420/006752 which recommends type 11 as the model of the program. In additions, the implementation of the program also resulted in some adverse effects to Islamic religious education in the region. By using qualitative method, this research found three essential data: the implementation of the PS5H in Kota Salatiga is different from the model recommended by the Decree, the PS5H indirectly influenced the Islamic education in Kota Salatiga, and the program has some direct effects towards children, teachers, and society physically, psychologically, and economically. In fact, sociologically pu, a program that one of the goals to bring the relationship of parents and children is actually in fact not achieved because children prefer to play with friends and still busy to school to follow extracurricular activities. Thus, a five-day school program in practice is almost no different from a six-day school program.
\end{abstract}

Keywords: the five days schooling program, islamic education, Kota Salatiga, effect 


\section{PENDAHULUAN}

$\mathrm{P}$ rogram sekolah lima hari yang biasa disebut dengan Full Day School (FDS) merupakan isu yang sangat panas diperbincangan oleh orang-orang yang bersentuhan dengan dunia pendidikan. Isu itu mencuat saat Menteri Pendidikan dan Kebudayaan, Muhadjir Effendy, mulai mewacakannya pada awal hingga pertengahan Agustus 2016 (Pramono, 2017: 3) dan kembali mendapat sorotan saat ia mengeluarkan Permendikbud Nomor 23 Tahun 2017 tentang Hari Sekolah. Peraturan ini memperoleh penolakan dari berbagai kalangan masyarakat, khususnya NU, yang kemudan melakukan demo besar-besaran di berbagai daerah, seperti Solo, Banyumas, Semarang, Cirebon, Rembang, Batang, Jombang, Pasuruan, Indramayu, Sleman, dan Mataram (Surabaya Pagi, 2017: "NU Tolak FDS"; Radar Bangka, 2017: "NU Tolak Sekolah Full Day"; Tribune Jateng, "PCNU Solo"; Suara NU, "20 Ribu Warga", 2017; Detiknews, "Ribuan Santri”, 2017; Kompas.com, "Tolak 'Full Day School”, 2017; Jawa Pos, "Belasan Ribu”, 2017; Republika, "Puluhan Ribu", 2017; Radar Kudus, "Sepuluh Ribu", 2017; Liputan 6, "Giliran", 2017; Bangsa Online, "DPRD dan Pesantren", 2017; Warta Bromo, "Tolak FDS", 2017; KR Jogja, "Datangi Bupati", 2017; Rilis, "Ribuan Nahdliyin", 2017; Suara NTB, “Terima Demo", 2017.

Selain NU ada 13 ormas yang juga mengambil sikap yang sama yang kemudian tergabung dalam Lembaga Persahabatan Ormas Islam. Mereka adalah Persatuan Islam, A-Irsyad, A-Islamiyah, Arrobithoh al-Alamiyah, Persatuan islam Tionghoa Indonesia, Mathlaul Anwar, Al Ittihadiyah, Az-Zikra, AlWasliyah, IKADI, Syarikat Islam Indonesia, Persatuan Tarbiyah Islamiyah (Perti), dan Dewan Da’wah Islamiyah (Duta, “Tak Direspon”, 2017).

Walaupun demikian, ada juga bagian masyarakat yang mendukung dan langsung memberlakukannya. Di Kabupaten Kulonprogo, sekolah lima hari ini sudah langsung diberlakukan di tingkat pendidikan dasar (SD-SMP) sejak tahun pelajaran 2017/2018, tetapi tidak di tingkat pendidikan menengah (HTW, Kepala Balai Diklat Pendidikan Menengah Kabupaten Kulonprogo, wawancara 11/10/2017).

Sebelum menjadi isu nasional, pro kontra pemberlakukan sekolah lima hari ini sudah terjadi di Jawa Tengah, ketika Gubernur Jawa Tengah mengeluarkan Surat Edaran Nomor
420/006752/2015 yang menghimbau satuan pendidikan di Jawa Tengah menyelenggarakan pendidikan selama lima hari.

Surat edaran ini memunculkan pro dan kontra. Mereka yang mendukung kebijakan sekolah lima hari beranggapan bahwa dengan berkurangnya satu hari di sekolah, anak mempunyai waktu lebih banyak melakukan kegiatan-kegiatan lainnya secara mandiri serta memberi waktu lebih bagi anak untuk memperoleh kembali semangat belajar, meningkatkan keeratan hubungan kekeluargaan, serta melaksanakan fungsi sosial dan pengembangan diri di luar sekolah.

Sedangkan kelompok-kelompok yang menentang kebijakan tersebut lebih melihat efek negatifnya. Argumen-argumen mereka antara lain: Pertama, peserta didik akan mengalami kejenuhan sehingga pemadatan jam pelajaran tidak akan efektif. Kedua, anak tidak akan dapat leluasa mengikuti kegitan ekstrakurikuler maupun kegiatan pengembangan lainnya karena waktunya sudah habis untuk jam pelajaran. Ketiga, harapan memiliki waktu lebih leluasa dengan orang tua hanya dapat dipenuhi oleh mereka yang orang tuanya juga memiliki ritme lima hari kerja, seperti PNS. Keempat, walaupun kebijakan tersebut berhasil diterapkan di daerah lain, kebijakan tersebut tidak cocok diberlakukan di Jawa Tengah karena etos pembelajaran yang berbeda. Kelima, dan ini yang sering muncul di kalangan para penggiat kegiatan keagamaan, adalah terancammnya kegiatan pembelajaran di madrasah diniyah maupun pesantren (Rachmat, 2015; Sumartyarini, 2015; Kemenag Provinsi Jawa Tengah, "Kebijakan Sekolah", 2015).

Kekhawatiran inilah yang mendorong beberapa tokoh dan organisasi masyarakat meminta kebijakan tersebut ditinjau ulang, seperti yang dilakukan oleh asosiasi pondok pesantren Nahdhatul Ulama' yang juga dikenal dengan Rabithah Ma'ahid Islamiyyah Nahdhatul Ulama (RMI NU). Dalam sebuah halaqah yang diselenggarakan pada 26 November 2015, Ketua Pengurus Pusat RMI NU, K.H. Abdul Ghoffar Rozien menyatakan menolak dan meminta Gubernur Jawa Tengah meninjau ulang kebijakan yang meresahkan tersebut (RMI “Tolak Kebijakan”, 27 November 2015).

Kota Salatiga merupakan salah satu wilayah yang memberlakukan kebijakan sekolah 5 hari bagi SMA/SMK Negeri. Kebijakan ini mengancam lembaga pendidikan madrasah diniyah (pendidikan 
nonformal) yang secara umum diselenggarakan sore hingga malam hari, khususnya lembaga pendidikan Islam yang memiliki jenjang pendidikan ' $u l y a .{ }^{1} \mathrm{Hal}$ itu karena sebagian besar peserta didiknya adalah anak-anak yang sekolah di jenjang pendidikan menengah (SMA/SMK/MA).

Persoalan yang hendak diungkap dalam penelitian ini adalah bagaimana pelaksanaan program sekolah lima hari di Kota Salatiga, bagaimana pendidikan keagamaan di lembaga pendidikan Islam di Kota Salatiga sebelum dan sesudah program tersebut dijalankan, dan apa akibat positif dan negatif pelaksanaan program sekolah lima hari kerja terhadap pendidikan keagaamaan di Kota Salatiga.

Walaupun hari sekolah sebagaimana diatur dalam Permendikbud Nomor 23 Tahun 2017 tidak jadi diberlakukan secara nasional para tahun ajaran 2017/2018 (akhirnya bersifat opsional, diserahkan kepada sekolah masing-masing) penelitian ini akan dapat menjadi pertimbangan bagi mereka yang akan memberlakukannya di tahun-tahun yang akan datang, seperti di Provinsi DIY yang rencananya akan memberlakukan ketentuan tersebut di tingkat SMA/SMK pada Januari 2018 (R, Guru PAI di Kabupaten Bantul, wawancara 28 Oktober 2017; S, pengawas PAI di Kabupaten Gunungkidul, wawancara 16 Nopember 2017; AJ, pengawas PAI di Kabupaten Kulonprogo, (wawancara 27/11/2017)

\section{Tinjauan Pustaka}

Sebagaimana telah disinggung di bagian awal bahwa Program Sekolah 5 Hari (PS5H) lebih lazim dikenal dengan Full Day School (FDS). Oleh karena itu untuk memberikan definisi PS5H kita dapat pula menengok apa itu FDS.

Istilah Full Day School (FDS) menurut Winurini $(2016,10)$ sepadan dengan After School Program (ASP) di beberapa negara yang secara umum memberlakukan program tersebut karena dilatarbelakangi oleh beberapa alasan, seperti ambisi orang tua untuk kemajuan pendidikan anaknya (Korea Selatan), mengurangi tingginya kriminalitas yang dilakukan oeh anak (Amerika Serikat), dan kebiasaan anak menyelesaikan tugas setelah jam sekolah (Singapura) (Winurni, 2016: 10). Program tersebut berdasarkan hasil penelitian yang dipublikasikan di Harvard Family Research Project

1 Dalam lembaga pendidikan Islam, ada tiga jenjang pendidikan yang dikenal, yaitu ula (setara dengan SD/ MI), wustha (setara dengan SMP/Mts), dan 'ulya (setara dengan SMA/SMK/MA) di tahun 2003 yang menunjukkan bahwa program ASP mampu meningkatkan perkembangan sosial, kepribadian, dan akademik anak (Winurni, 2016: 10).

Di Indonesia, istilah ini mulai dikenal sejak tahun 1990an ketika bermunculan sekolah dengan label sekolah unggulan (Siregar, 2017:286) dan kembali mencuat 3 tahun yang lalu (dalam konteks Jawa Tengah, ketika gubernur Jateng mengeluarkan surat edaran) dan satu tahun terakhir (dalam konteks nasional ketika Mendikud mewacanakan sekolah lima hari hingga munculnya Permendikbud Nomor 23 Tahun 2017 dan Peraturan Presiden Nomor 87 Tahun 2017).

Walaupun dalam Permendikbud Nomor 23 Tahun 2017 tidak dikenal istilah FDS, tetapi masyarakat umum lazim menggunakan istilah tersebut ketika berbicara tentang Permendikbud dimaksud. Hal itu dapat dipahami karena ada kesamaan antara FDS yang sudah lebih dahulu dikenal masyarakat dengan hari sekolah yang diatur dalam permendikbud. Keduanya menerapkan jam sekolah yang lebih panjang daripada jam sekolah sebelumnya (8-9 jam). Selain itu, program sekolah lima hari juga mengadopsi sistem FDS (Roshayanti dkk. 2015: 97) dan beberapa sekolah yang menerapkan FDS juga menerapkan sekolah lima hari (SF, salah satu orang tua siswa di sekolah yang memberlakukan FDS, wawancara, 2017) dengan jam sekolah antara 6.45-16.00 WIB (bandingkan Baharuddin dalam Siregar, 2017: 283; Nastiti, 2016; Andrianingsih, 2016:1). Dengan demikian, sekolah yang menerapkan lima hari sekolah tentu menerapkan FDS.

Pelaksanaan Sekolah Lima Hari sebenarnya bukan suatu hal yang baru. Program ini telah berjalan di sekolah-sekolah BPK PENABUR pada tahun 2002. Model pelaksanaannya mengacu hasil penelitian Sitepu $(2002 ; 2004)$ yang akhirnya merekomendasikan tiga model. ${ }^{2}$ Ketiga model

2 Rekomendasi atas tiga model sekolah lima hari ini merupakan sebuah hasil perjalanan panjang dengan menggunakan data kualitatif dan duantitatif. Di awal penelitiannya, Sitepu menemukan 48 model sekolah lima hari. Dari 48 model tersebut kemudian dilakukan penguranagn kombinasi-kombinasi yang saling bertentangan sehingga tersisa 40 model. Dengan menggunakan beberapa kriteria dan mempertimbangkan data penelitian yang diperoleh, akhirnya Sitepu merekomendasikan tiga model pelaksanaan sekolah lima hari yang sebenarnyapun masih dapat dikategorikan lagi ke dalam dua jenis berdasarkan satuan pelajarannya. 
tersebt adalah model 10, 11, dan 13 yang kemudian dapat dibagi lagi menjadi dua kategori: model yang menganut satuan pelajaran yang berdurasi tetap (model 11 dan 13) dan model yang menganut pengurangan durasi satuan pelajaran (model 10). Penjelasan secara sederhana mengenai ketiga model dapat dilihat di tabel 1.

Tabel 1 Tiga model Sekolah Lima Hari

\begin{tabular}{llll}
\hline Variabel & Model 10 & Model 11 & Model 13 \\
\hline Hari Sekolah & Senin s.d. Jum’at & Senin s.d. Jumat & Senin s.d. Jumat \\
Hari Sabtu & Libur Total & Libur Total & Libur Total \\
Satuan jam pelajaran & Berkurang & Tetap & Tetap \\
Jam Sekolah per hari & Tetap & Bertambah & Tetap \\
Jam Pelajaran per minggu & Tetap & Tetap & Berkurang \\
Kegiatan Ekstrakurikuler & Sesudah jam pelajaran & Sesudah jam pelajaran & Sesudah jam pelajaran \\
\hline Sumber: Sitepu $(2002,50)$ & & &
\end{tabular}

Tidak dapat dipungkiri bahwa sudah banyak tulisan yang mengkaji sekolah yang menerapkan FDS yang sebagian besar mengaitkan program tersebut dengan pendidikan Islam (Oktaviani, 2017; Siregar, 2017) dan memotret pelaksanannya di lembaga pendidikan Islam (Nastiti, 2017; Seftiana, 2017; Hawi, 2015;).

Selain itu ada juga tulisan-tulisan yang berusaha membandingkan antara sekolahsekolah yang melaksanakan FDS dan yang tidak melaksanakan program tersebut. Hasil penelitian Zvoch dkk. (2008) menunjukkan bahwa anak-anak yang sekolah di FDS memiliki tingkat literasi yang lebih tinggi daripada yang tidak sekolah di FDS. Hal yang hampir sama juga diungkapkan oleh Gullo (2006) dan Cryan dkk. (1992). Hasil penelitian Gullo (2006) megatakan bahwa anak-anak yang belajar di TK FDS secara signifikan memiliki nilai matematika dan kemampuan baca yang lebih tinggi daripada yang sekolah di TK setengah hari, sedangkan hasil penelitian Cryan dkk (1992) mengatakan bahwa keikutsertaan anak-anak di TK FDS memiliki hubungan yang positif dengan performa dia di sekolah berikutnya (SD), khususnya di kelas 1 .

Selain itu, ada juga penelitian yang secara langsung menggunakan istilah PS5H. Sebuah survei tentang program tersebut pernah dimuat dalam situs PGRI. Survei dilakukan di Salatiga dalam rentang waktu 27 Juli 2015 hingga 16 Agustus 2015. Dalam penelitian yang dipublikasikan pada 22 Agustus 2015 tersebut didapatkan data bahwa 50 persen responden memberikan apresiasi postif. Kebijakan tersebut dianggap sebagai upaya mewujudkan keseimbangan intelektual, emosi, dan kerohanian siswa. Program tersebut memindahkan alokasi pembelajaran semata.

Di samping itu, dikemukakan juga bahwa respon negatif diberikan oleh responden dalam empat hal, yakni kejenuhan dan kelelahan siswa, banyaknya PR yang diberikan oleh guru, terbatasnya daya tampung masjid dan kantin sekolah, serta pentingnya kreatifitas guru dalam mengajar. Dari tulisan tersebut belum terlihat ada yang tertarik membahas akibat pelaksanaan PS5H terhadap lembaga pendidikan Islam.

\section{METODE PENELITIAN}

Penelitian ini dilakukan dengan menggunakan pendekatan kualitatif. Data dikumpulkan dengan cara wawancara, studi dokumen, dokumentasi, dan observasi. Wawancara dilakukan kepada orang-orang yang terlibat langsung dalam fokus penelitian, seperti pemangku kebijakan di Dinas Pendidikan dan Kebudayaan Kota Salatiga, Kepala Sekolah SMA/SMK pelaksana program sekolah lima hari, peserta didik, orang tua, dan pelaku pendidikan keagamaan lainnya. Cara ini ditempuh terutama untuk mengetahui bagaimana pendapat mereka terhadap pelaksanaan dan akibat program sekolah lima hari dan akibat-akibat lain yang ditimbulkannya khususnya dalam pendidikan Islam. Selain itu, wawancara juga digunakan untuk menggali informasi tentang gambaran pendidikan keagamaan sebelum program tersebut dilaksanakan. Sedangkan telaah dokumen dan dokumentasi dilakukan untuk mengetahui dan membandingkan keaktifan peserta didik dalam mengikuti pendidikan keagamaan sebelum dan sesudah program sekolah lima hari kerja diberlakukan. 
Untuk menganalisis data, peneliti menggunakan tehnik analisis yang ditawarkan oleh Miles dan Huberman (dalam Agusta, 2003:10-11) yang terdiri dari tiga tahapan utama, yaitu reduksi data, penyajian data, dan penarikan kesimpulan. Ketiga tahapan ini tidak dilakukan secara berurutan tetapi dilakukan secara bersamaan dan terus menerus sejak peneliti masih berada di lapangan hingga tahap penulisan.

\section{PEMBAHASAN}

\section{Pelaksanaan Program Sekolah Lima Hari di Kota Salatiaga}

Sebagaimana telah disebutkan di bagian sebelumnya bahwa PS5H bukanlah program yang baru. Program ini sudah diberlakukan di sekolahsekolah BPK PENABUR di tahun ajaran 2002/2003 setelah dilakukan feasibilty study (Sitepu, 2004). Program yang sama juga telah dilaksanakan oleh SMAN 1 Girsang Sipangan Bolon Kabupaten Simalungun Provinsi Sumatera Utara pada tahun ajaran 2012/2013 (lih. Novalina, 2013). Program ini menjadi hangat diperbincangkan di wilayah Jawa Tengah sejak muncul Surat Edaran Gubernur Jawa Tengah Nomor 420/006752/2015 tentang Penyelenggaraan Kegiatan Pendidikan pada Satuan Pendidikan di Jawa Tengah. Akibatnya, beberapa sekolah, khususnya sekolah pada jenjang menengah di Jawa Tengah menyelenggarakan proses pembelajaran lima hari dalam seminggu.

Akan tetapi, sebelum Surat Edaran tersebut muncul, beberapa sekolah di Salatiga, khususnya sekolah di bawah Yayasan Kristen Satya Wacana sudah terlebih dahulu menerepkannya. Bahkan, program ini merupakan salah satu strategi SMA Kristen 1 Salatiga untuk dapat bersaing dengan lembaga pendidikan lainnya (Noya, 2014). Strategi tersebut juga diterapkan oleh SMP Kristen Lentera di Ambarawa (Kastanja, 2013). Setelah surat edaran yang menjadi salah satu landasan yuridis pelaksanaan sekolah lima hari di Kota Salatiga muncul, ada dua puluh satuan pendidikan yang menyelenggarakan proses pembelajaran lima hari.

Setelah surat edaran tersebut muncul yang kemudian ditindaklanjuti dengan Surat Keputusan Kepala Pendidikan Provinsi Jawa Tengah Nomor 420/03737 tentang Suplemen Penyusunan Kalender Pendidikan 5 (Lima) Hari Belajar per Minggu Tahun Pelajaran 2015/2016 dan juga Surat Kepala Dinas Pendidikan Provinsi Jawa Tengah Nomor 420/03738 yang ditujukan kepada seluruh Kepala Dinas Pendidikan Kabupaten/Kota di Jawa Tengah,
Dinas Pendidikan Kota Salatiga membuat surat untuk kepala sekolah dan juga komite sekolah dan mengundang mereka untuk keperluan sosialisasi. Karena hanya bersifat edaran maka pelaksanaan program sekolah lima hari belajarbersifat himbauan, bukan sebuah keharusan. Keputusan mengikuti surat edaran ataupun tidak diserahkan kepada kebijakan satuan pendidikan. Walaupun demikian, satuan pendidikan tingkat menengah yang berada di bawah pengelolaaan pemerintah (negeri) harus melaksanakan program tersebut sebagai uji coba.

Dalam Surat Keputusan Kepala Dinas Pendidikan Provinsi Jawa Tengah Nomor 420/03737 tentang Suplemen Pedoman Penyusuanan Kalender Pendididkan 5 (Lima) Hari per Minggu Tahun Pelajaran 2015/2016 Bab I Pasal 1 ayat 6 disebutkan bahwa pelaksanaan pendidikan yang peyelenggaraannya lima hari dalam seminggu dilakukan dari hari Senin hingga hari Jum'at. Kegiatan-kegiatan pembelajaran maupun kegiatan lain yang semula dilaksanakan pada hari Sabtu harus didistribusikan ke dalam hari Senin hingga Jum'at tanpa mengurangi jumlah jam pelajaran per minggu dan juga tidak mengurangi durasi waktu pembelajarannya. Dengan melihat ketentuan ini dapat kita ketahui bahwa ketentuan pelaksanaan sekolah lima hari belajar yang dikehendaki oleh Dinas Pendidikan Provinsi Jawa Tengah adalah pelaksanaan program model 11 sebagaimana yang diperkenalkan oleh Sitepu (2002: 50), yang berarti proses pembelajaran dilaksanakan Senin hingga Jum'at, satuan jam pelajaran dan jumlah jam pelajaran per minggu bersifat tetap, sedangkan jam sekolah perhari bertambah. Hari Sabtu libur total, dan kegiatan ekstrakurikuler dilaksanakan setelah jam pelajaran.

Akan tetapi, pelaksanaan program tersebut di lapangan ternyata tidak sesuai dengan aturan dalam ayat tersebut. Hal yang paling menonjol adalah pelaksanaan kegiatan ekstrakurikuler. Berdasarkan bunyi pasal 1 ayat 6 Surat Keputusan Kepala Dinas Pendidikan Provinsi Jawa Tengah Nomor 420/03737 kegiatan ekstrakurikuler harus diselenggarakan pada hari Senin hingga hari Jum'at, setelah pelaksanaan kegiatan belajar mengajar. Artinya, sama dengan penjelasan Sitepu tentang model 11 yang diperkenalkannya dalam Program Sekolah Lima Hari, hari Sabtu harus libur total.

"Teorinya, Bu. Teorinya. Teorinya ekstra itu
dilakukan sepulang sekolah. Teorinya. Jadi
anak itu belajar sampai jam terakhir itu jam 
setengah empat. Setengah empat sampai setengah lima itu ekstra. Tapi nyatanya pada hari Sabtu yang teorinya itu free tapi anakanak pada ngambil hari Sabtu untuk kegiatan. Bahkan kalau perlu anak-anak itu Minggu pun anak-anak itu pun kegiatan. Itu anak SMA 1. Teorinya free, tapi nyatanya tidak. Otomatis, kalau anak-anak ada kegiatan, kita tidak ndampingi juga nanti dipersalahkan. Begitu. Nanti kalau ada apa-apa orang tuanya juga klaim. Ini ada kegiatan kok pembinanya ndak ada. Mau tidak mau kita harus datang mendampingi anak-anak." (wawancara dengan JR, 11/12/2015)

Penyelenggaraan kegiatan ekstrakurikuler di hari Sabtu bukan hanya terjadi di SMAN 1 Salatiga, tetapi juga di SMKN 3 Salatiga, SMKN 2 Salatiga, dan SMKN 1 Salatiga. Praktik pelaksanaan sekolah lima hari ini menimbulkan respon yang berbeda-beda, ada yang menyetujuinya tetapi juga ada yang tidak mendukungnya. Meskipun terasa melelahkan tetapi beberapa peserta didik mengaku lebih menyukai program sekolah lima hari daripada enam hari. Alasan terbanyak yang mereka ajukan adalah mereka memiliki hari libur lebih banyak daripada sekolah enam hari belajar.

"Istirahatnya lebih banyak. Sabtu bisa digunakan untuk nyuci, nyetrika, bersihbersih. Walaupun ada ekstra tapi kan masuknya agak siangan. Jam delapan, jam sembilan." (wawancara dengan Alf, 7/12/2015).

"Enak. Menurutku enak, Bu. Bisa istirahat banyak. Kalau Sabtunya kan libur, bisa free semua." (wawancara dengan F, 7.12.2015)

Hal berbeda justru dirasakan oleh orang tua dan beberapa tokoh masyarakat, baik secara individual maupun yang tergabung dalam sebuah organisasi tertentu. Majelis Ulama Indonesia (MUI) Kota Salatiga, misalnya, pada 23 Oktober 2015 menyelenggarakan sebuah acara yang dihadiri oleh PGRI, Kesbanglinmas, Kementerian Agama, dan Dinas Pendidikan Kota Salatiga. Ada dua persoalan penting yang dibahas dalam pertemuan tersebut, yakni terkait ISIS dan program sekolah lima hari.

Keputusan penting dengan Program Sekolah Lima Hari adalah dikeluarkannya fatwa MUI Kota Salatiga Nomor 01/MUISA/XI/2015 tentang Lima Hari Kerja Bidang Pendidikan. Fatwa Hukum yang kemudian dikirimkan ke Gubernur Jawa Tengah dengan surat Ketua MUI Salatiga Nomor 17/MUI/SLTG/X/2015 ini berisi rekomendasi agar pemerintah menarik kembali program sekolah lima hari kerja dan mengembalikannya ke enam hari kerja. Dalam fatwa tersebut disampaikan dikmukakan beberapa ayat Alquran dan beberapa pertimbangan teologis religius lainnya sebaga pertimbangan. Akan tetapi, yang perlu peneliti sebutkan di sini adalah bahwasanya salah satu alasan rekomendasi tersebut adalah program sekolah lima hari pada satuan pendidikan tingkat dasar dan menengah dapat mematikan pendidikan agama dan keagamaan yang seharusnya dilindungi oleh pemerintah.

\section{Lembaga Pendidikan Islam Sebelum dan Sesudah Pelaksanaan Program Sekolah Lima Hari}

Sebelum membicarakan pelaksanaan PS5H di Kota Salatiga, perlu dijelaskan secara singkat bahwa lembaga pendidikan Islam adalah

"suatu wadah atau sistem hubungan sosial yang terorganisir mewujudkan nilai-nilai dan tata cara umum tertentu secara sadar dan terencana melalui belajar dan proses pembelajaran agar peserta didik secara aktif mengembangkan potensi dirinya sesuai dengan Islam" (Hidayat, 2013:117).

Bentuk dan jenisnya pun bermacam-macam. Pada zaman Rasulullah lembaga pendidikan itu berupa rumah, khususnya rumah al Arqam bin al-Arqam yang sering digunakan sebagai tempat Nabi mengajar para sahabatnya. Setelah masyarakat muslim mulai terbentuk, ada tempat lain yang digunakan sebagai lembaga pendidikan, yaitu masjid. Selain itu, ada pula shuffah (kediaman para sufi), ribath, badiah, kuttab, manazil al-ulama' (kediaman para ulama'), hawanit al-warraqin (toko buku), al-shalunat al-adabiyyah (sanggar seni dan sastra), maktabah (perpustakaan), qushur (pendidikan rendah di istana), dan majlis muhadharah. Seiring dengan masyarakat yang terus berkembang, muncul pula lembaga pendidikan lainnya, seperti kuttab, madrasah, dan al-jami'ah (Hidayat, 2013: 115-130; Andriani, 2016:123-136).

Dalam konteks Indonesia, dikenal beberapa lembaga pendidikan islam, seperti pondok pesantren, madrasah, surau, dan meunasah (Hidayat, 2013; Akhiruddin, 2015) dan berdasarkan PP Nomor 5 Tahun 2007 pendidikan agama dapat diselenggarakan dalam jalur formal maupun nonformal serta berjenjang maupun tidak berjenjang. Dalam pasal 21 Peraturan Pemerintah 
Nomor 5 Tahun 2007 disebutkan bahwa pengajian kitab, majelis taklim, pendidikan al-qur'an, diniyah takmiliyah, dan bentuk lain yang sejenis adalah bentuk pendidikan keagamaan pada jalur nonformal. Akan tetapi, karena majelis taklim merupakan bentuk pendidikan keagamaan yang secara umum diikuti oleh anggota masyarakat yang secara umum sudah berada di luar usia sekolah dasar dan menengah maka maka yang akan disinggung dalam tulisan ini hanyalah pendidikan Alqur'an, madarash diniyah, dan pondok pesantren.

Kota yang memperoleh "hibah" beberapa wilayah dari Kabupaten Semarang (karena pemekaran) (salatiga.go.id) ini memiliki sejumlah lembaga pendidikan keagamaan Islam yang bersifat non formal. Lembaga tersebut terdiri dari tiga kategori: TPA (Taman Pendidikan Alqur'an), madin (madarasah diniyah), dan pontren (pondok pesantren). Ketiga lembaga pendidikan tersebut menyebar di empat wilayah kecamatan Kota Salatiga. Ketiga jenis lembaga inilah yang menjadi tulang punggung penyelenggaraan pendidikan keagamaan di Kota Salatiga. Ketiganya memiliki peserta didik, ritme dan proses kegiatan yang berbeda.

TPA adalah lembaga pendidikan yang biasanya untuk anak-anak. Materi utama yang diajarkan adalah Alqur'an, khususnya tajwid, meskipun juga tidak menutup kemungkinan diajarkan pula materi-materi yang lain, seperti akhlak dan doa-doa pendek. Kegiatan dilaksanakan di sore hari setelah ashar, sekitar jam setengah empat sore, hingga jam setengah lima sore.

Madarash diniyah biasanya merupakan jenjang pendidikan keagamaan Islam lanjutan setelah TPA. Hampir sama dengan lembaga pendidikan formal, madrasah diniyah juga dibagi menjadi tiga tingkatan: madrasah diniyah ibtidaiyyah, madrasah diniyyah tsanawiyyah, dan madrasah aliyah. Pendidikan keagamaan di jenjang ini juga diselenggarakan di sore hari (setelah pulang dari sekolah formal) dan malam hari. Untuk jenjang madrasah diniyyah ibtidaiyyah kelas rendah, proses belajar di kelas biasanya dilakukan sore hari hingga menjelang maghrib. Sedangkan madrasah diniyyah ibtidaiyyah kelas atas hingga madrasah diniyyah aliyah diselenggarakan malam hari. Madrasah Diniyyah Tsanawiyah dan aliyah biasanya dikelola oleh pondok pesantren karena sarana dan prasarana serta sumber daya manusianya lebih mendukung. Sulit ditemukan madrasah diniyyah tingkat aliyah yang berdiri sendiri tanpa ada pondok pesantren di belakangnya.
Untuk memberikan gambaran kegiatan pendidikan keagamaan yang diselenggarakan oleh madrasah diniyyah ibtidaiyyah kelas atas dan tingkat tsanawiyah serta aliyah berikut peneliti uraikan kegiatan yang diselenggarakan oleh Pondok Pesantren Sunan Giri di Krasak, Ledok, Argomulyo, sebagai contohnya, sebuah pondok pesantren yang memiliki pendidikan nonformal dari jenjang TPA hingga madin tingkat aliyah.

Pondok Pesantren Sunan Giri berada di Jl. Argowilis No. 15-16 Dusun Krasak, Desa Ledok, Kecamata Argomulyo, Salatiga. Aktivitas pondok pesantren yang didirikan tahun 1992 ini sudah mulai sejak menjelang subuh. Setelah shalat subuh, para santri mengaji Alqur'an dengan metode sorogan hingga sekitar jam enam pagi. Santri yang tidak sekolah melanjutkan mengaji kitab kuning, sedangkan santri yang belajar di lembaga formal berangkat ke sekolah.

Setelah ashar hingga sekitar jam lima dilaksanakan pembelajaran untuk TPA dan juga madrasah diniyyah ibitidaiyyah kelas 1 hingga kelas 5A. Sedangkan kelas 5B, madrasah diniyyah tsanawiyyah, hingga madrasah aliyah mengikuti kegiatan musyawarah, yakni membahas materimateri yang telah maupun akan dipelajari. Kegiatan ini biasanya dipandu oleh santri yang lebih senior. Sedangkan kegiatan inti pembelajaran di madrasah diniyyah itu sendiri dilaksanakan setelah isya' hingga sekitar jam sepuluh malam. Sementara selepas maghrib hingga isya' kegiatan keagamaan yang diselenggarakan adalah mengaji Alqur'an.

Selain kegiatan rutin harian, ada juga kegiatan yang bersifat mingguan, seperti pengajian untuk umum yang diselenggarakan setiap Selasa malam. Pengajian ini dilaksnakan setelah shalat isya' hingga sekitar jam sembilan malam dan diikuti oleh penduduk sekitar. Mereka berduyun-duyun ke lokasi Pondok Pesantren Sunan Giri untuk mengikuti ceramah keagamaan yang diberikan oleh Rama Kyai.

Kegiatan pendidikan tersebut sudah berlaku sebelum program lima hari sekolah muncul. Setelah muncul surat edaran gubernur tentang program tersebut dan beberapa satuan pendidikan melaksnakannya tidak ada perubahan yang mencolok. Jadwal, ritme, dan proses pendidikan tetap berlangsung seperti biasanya.

Akan tetapi, program lima hari sekolah berimbas langsung terhadap santri yang sekaligus menjadi peserta didik satuan pendidikan pelaksana program tersebut. Imbas tersebut secara rinci dapat dilihat dalam uraian berikutnya. Hal yang ingin disampaikan di sini adalah bahwa dengan adanya 
program lima hari sekolah yang berakibat pada jam kepulangan peserta didik lebih sore daripada sebelumnya, akhirnya madrasah diniyyah pun harus menyesuaikan kebijakan. Dalam beberapa hal, madrasah diniyyah harus "mengalah" dengan kebijakan lembaga pendidikan formal.

Salah satu contoh kebijakan yang dibuat oleh pihak madrasah diniyyah adalah memberikan keringanan kepada santri yang sekolahnya memberlakukan program lima hari sekolah. Mereka boleh terlambat mengikuti kegiatan musyawarah, bahkan tidak mengikuti kegiatan tersebut sama sekali. Padahal, sebelumnya, musyawarah merupakan kegiatan wajib yang harus diikuti oleh santri madrasah diniyyah kelas 5B hingga madrasah aliyah. Sebagai kegiatan yang bersifat wajib maka mereka yang tidak mengikuti kegiatan tersebut (tanpa alasan yang dapat diterima) akan memperoleh hukuman.

“Telat saja disuruh push up. Telat lima menit 10 kali, sepuluh menit dua puluh kali, lima belas menit 30 kali, dan seterusnya. Lha itu ada aturannya. Push upnya di depan, kadang di kantor. Kadang kalau nggak ikut musyawarah disuruh baca surat yasin. Dan banyak konsekwensinya" (FGD, 7/12/2015).

Tidak ikutnya santri dalam kegiatan musyawarah lebih dikarenakan rasa capai sepulang sekolah. Begitu sampai di pondok mereka langsung mandi dan meluangkan waktu untuk istirahat. Dengan kesadaran sendiri mereka ikut bergabung dalam kegiatan musyawarah meskipun terlambat, tetapi tidak jarang menunggu diopyak-opyak pengurus pondok pesantren. Menyadari kedaan yang demikianlah para ustadz madrasah diniyyah yang secara umum juga pengurus pondok pesantren akhirnya memberi dispensasi kepada para santri yang baru pulang dari sekolah dalam keadaan kelelahan.

"Lha dari kepengurusan yang agak kerepotan itu, anak pulangnya jam lima. Dari kami itu kalau harus ngopyak ngopyak suruh ke madrasah itu kan rada mesakne, Bu. Mereka jam lima baru pulang kemudian dipyak opyak, 'ayo ndang salin, mandi, shalat habis itu ke madrasah' itu kan kasihan, mereka kan baru pulang. Otomatis mereka tidak bisa ikut madrasah. Tidak bisa ikut musyawarah. Otomatis. Waktu tinggal setengah jam. Otomatis mereka tidak dapat mengikuti kegiatan musyawarah. Ini kan sangat disayangkan. Padahal Pondok Pesantren
Saunan Giri itu 70\% santrinya ikut sekolah formal. Dulu, ketika saya baru di sini sih baru sekitar $15 \%$, kalau sekarang sudah sekitar $70 \%$. Banyak anak yang sekolah" (wawancara dengan Msb, 7/12/2015)

"Akhirnya mereka diperingan. Untuk anak sekolah kalau benar-benar nggak bisa pulang cepat ya silakan mengikuti sekolah. Mau nggak mau kan harus mengikuti sekolah nggih. Kalau ada kegiatan di sekolahan ya silakan ikut di skeolahan. Terus Rama Yai nggih ngendika, 'sudah, anak sekolah diperingan saja"' (wawancara dengan Msb, $7 / 12 / 2015)$

Berlakunya program sekolah lima hari yang kemudian diikuti dengan penyesuaian oleh madrasah diniyyah justru dimanfaatkan santri untuk tidak mengikuti pendidikan di madrasah diniyyah sama sekali. Bahkan, dalam beberapa hal, santri menjadikan kedua lembaga pendidikan (sekolah dan madrasah/pondok pesantren) sebagai kambing hitam untuk mengelak dari tugas belajar maupun menghindar dari hukuman.

"Lha itu ada aturannya. Push upnya di depan, kadang di kantor. Kadang kalau nggak ikut musyawarah disuruh baca surat yasin. Dan banyak konsekwensinya. Sebenarnay di luar itu banyak tulisannya. Tapi kadang kalau bisa ngeles ya bisa bebas. Bebas dari hukuman itu lho Bu. Maksudnya tadi kan kalau di sekolah kan begini begini begini. Akhirnya kita diberi toleransi" (FGD, 7/12/2015).

Keringanan kedua yang diberikan oleh pihak madrasah diniyyah dan pondok pesantren adalah dengan mengurangi beban hafalan.

"Akhirnya mereka diperingan. Untuk anak sekolah kalau benar-benar nggak bisa pulang cepat ya silakan mengikuti sekolah. Mau nggak mau kan harus mengikuti sekolah nggih. Kalau ada kegiatan di sekolahan ya silakan ikut di skeolahan. Terus Rama Yai nggih ngendika, 'sudah, anak sekolah diperingan saja'. Kasihan anak-anak, Bu. Sini dipleter suruh hafalan, suruh nambal kitab, ngesahi kitab, maknani kitab, padahal dari sekolahan sudah capai. Terus, Rama Yai, 'kalau hafalan, anak yang nonformal biasanya itu hafalan 10 berarti anak yang formal, yang ikut sekolah, lima saja. Separuhnya saja. Akhirnya kita yang ngalah" (wawancara denga Msb, 7/12/2015) 
Selain berakibat pada diturunkannya standar yang diberlakukan oleh madrasah diniyyah dan pondok pesantren, program sekolah lima hari juga berakibat pada berkurangnya tenaga pengajar di TPA yang kebetulan masih duduk di bangku sekolah tingkat SMA/SMK/MA. Apabila program ini diberlakukan kepada seluruh satuan pendidikan di jenjang menengah maka akan makin banyak pengajar di TPA yang masih menjadi peserta didik di SMA/SMK/MA tidak bisa lagi berkecimpung dalam pengajaran TPA.

\section{Dampak Pelaksanaan Program Lima Hari Sekolah di Kota Salatiga \\ Dampak Fisik}

Dampakyang terlihat nyata daripemberlakuan sekolah lima hari kerja adalah kecapaian secara fisik yang dialami bukan hanya oleh peserta didik tetapi juga oleh guru. Berdasarkan Peraturan Menteri
Pendidikan dan Kebudayaan Nomor 69 Tahun 2013 tentang Kerangka Dasar dan Struktur Kurikulum Sekolah Menengah Atas/Madrasah Aliyah, jam pelajaran efektif yang harus dipenuhi per minggu oleh kelas X SMA/MA adalah 42 jam pelajaran (JP), kelas XI SMA/MA $44 \mathrm{JP}$, dan kelas XII SMA/MA adalah 44 JP. Sedangkan untuk sekolah kejuruan (SMK/MAK), jumlah jam pelajaran yang harus dipenuhi untuk tiap-tiap kelas adalah $48 \mathrm{JP}$, dari kelas X hingga kelas XII SMK/MAK, dengan durasi waktu sama ( 1 jam pelajaran sama dengan 45 menit).

Artinya, beban belajar dan mengajar peserta didik dan guru di lima hari belajar lebih berat daripada yang enam hari. Oleh karena itu, bukan hal yang mengherankan apabila jadwal berakhirnya jam pelajaran di sekolah pelaksana lima hari belajar juga lebih lama. Perbandingan jadwal berawal dan berakhirnya pelajaran dapat dilihat dari tabel 4 .

Tabel 4 Perbandingan jadwal pelajaran antara enam hari dan lima hari belajar

\begin{tabular}{|c|c|c|c|c|c|c|}
\hline $\begin{array}{l}\text { Satuan } \\
\text { Pendidikan }\end{array}$ & SMAN 1 & & SMKN 3 & & SMAN 2 & \\
\hline Hari & 6 Hari & 5 Hari & 6 Hari & 5 Hari & 6 Hari & 5 Hari \\
\hline Senin & $07.30-13.45$ & $07.00-16.10$ & $07.00-14.15$ & $07.00-16.45$ & $07.00-14.15$ & $07.00-15.15$ \\
\hline Selasa-Kamis & $07.00-14.30$ & $07.00-15.30$ & $07.00-15.45$ & $07.00-16.45$ & $07.00-13.45$ & $07.00-15.15$ \\
\hline Jum’at & $07.00-11.15$ & $07.00-11.10$ & $07.00-11.00$ & $07.00-11.00$ & $07.00-11.00$ & $07.00-13.00$ \\
\hline Sabtu & $07.30-13.45$ & Ekstrakurikuler & $07.00-13.45$ & Ekstrakurikuler & $07.00-13.45$ & Libur \\
\hline $1 \mathrm{JP}$ & 45 menit & & 45 menit & & 45 menit & \\
\hline
\end{tabular}

Dengan melihat perbandingan jam kepulangan sebagaimana ditujukkan tabel 4, kita dapat mengetahui bahwa jam kepulangan lima hari sekolah lebih lama. Lagi pula, setelah jam belajar selesai, masih ada kegiatan-kegiatan ektrakurikuler yang dilaksanakan pada hari Senin hingga Jum'at, dan Sabtu. Selain kegiatan ekstra tersebut, peserta didik juga kadang maasih harus mengerjakan tugastugas sekolah maupun kegiatan tambahan lain berupa les dan pendalaman materi.

Dengan demikian, terlihat jelas beban yang harus ditanggung bukan hanya oleh guru tetapi juga oleh peserta didik. Oleh karena itu, bukan hal yang mengherankan apabila secara fisik mereka merasa sangat kecapaian. Bahkan, menurut pengakuan salah satu guru yang sekolahnya menerapkan sekolah lima hari belajar, libur dua hari di akhir pekan tidak cukup untuk mengembalikan rasa capai yang dirasakan di hari-hari sebelumnya.

"capainya lima hari itu diobati hari Sabtu dan Minggu itu nggak habis. Nggak pulih. Saya lima hari kerja itu nanti di rumah dua hari Sabtu dan Minggu libur, istirahat dua hari capainnya nggak hilang" (wawancara dengan JR, 11/12/2015).

Rasa capai juga dirasakan oleh peserta didik, lebih-lebih mereka yang masih aktif mengikuti kegiatan pendidikan keagamaan di madrasah diniyah maupun kegiatan lain yang diselenggarakan oleh pondok pesantren. Seperti halnya yang terjadi di Pondok Pesantren Sunan Giri, sepulang dari sekolah, mereka harus mengikuti kegiatan "musyawarah" yang diselenggarakan oleh pondok pesantren dari pukul empat sore hingga menjelang maghrib. Kegiatan ini berupa kegiatan telaah bersama tentang pelajaran yang sudah diajarkan maupun yang akan dibahas nantinya.

Untuk dapat lebih memahami bagaimana beban yang harus ditanggung oleh peserta didik, terutama yang juga aktif terlibat dalam kegiatan pendidikan keagamaan di pondok pesantren, berikut peneliti sampaiakan ilustrasi kegiatan 
harian seorang peserta didik yang belajar di SMAN 1 Salatiga, salah satu satuan pendidikan pelaku lima hari belajar.

Pagi-pagi sekali, sekitar jam empat Azza bangun tidur dan shalat shubuh yang dilanjutkan dengan mengikuti kegiatan sorogan di Pondok Pesantren Sunan Giri. Sepulang dari sana, Azza harus membantu kedua orang tuanya melakukan pekerjaan rumah seperti menyapu atau pekerjaan lainnya hingga sampai jam enam pagi atau setengah tujuh. Setelah itu, Azza berangkat ke sekolah dan belajar di sana hingga jam empat lebih. Walaupun sebenarnya kelas berakhir jam setengah empat sore, tetapi masih ada kegiatan ataupun tugas lain yang harus dikerjakan di sekolah. Sesampai di rumah sudah jam lima lebih dan masih harus dipanggilpanggil untuk mengikuti kegiatan madrasah di pondok pesantren. Selesai maghrib Azza mengikuti pelajaran di madrasah (tingkat aliyah) di Pondok Pesantren Sunan Giri hingga sekitar jam sepuluh. Baru setelah itu Azza pulang ke rumah.

Kegiatan yang seperti itu berulang setiap hari. Pernah suatu ketika Azza mengeluh kepada bapaknya yang mengatakan dia sangat kecapaian karena harus pulang terlalu sore sehingga tidak cukup istirahat sebelum melanjutkan kegiatan di pondok pesantren. Untuk memperbesar semangat Azza, ayahnyapun membesarkan hatinya dengan mengatakan bahwa semua itu hanya akan berlangsung selama empat bulan karena setelah itu Azza selesai pendidikan jenjang menengah dan melanjutkan pendidikan selajutnya di jenjang pendidikan tinggi. "Gur patang sasi, Le. Betahna"3 (wawancara dengan MC, 7 Desember 2015). Melihat kegiatan harian Azza yang seperti itu, ayahnya mengaku sering tidak tega. Kasihan melihat anaknya kelelahan sepulang dari sekolah sehingga tidak tega lagi menyuruh dan mengingatkan untuk pergi ke madrasah sepuang dari sekolah di SMA. Rasa capai itu akan berlipat ganda apabila peserta didik tersebut juga seorang santri "muqim" dan juga peserta didik SMKN 3 Salatiga. Hal itu karena sekolah ini memberlakukan sistem blocking mata pelajaran.

Sistem blocking adalah sistem yang membagi mata pelajaran dan kelas menjadi dua kategori: produktif, dan normatif. ${ }^{4}$ Mata pelajaran normatif

3 "Cuma empat bulan, Nak. Bertahanlah!"

4 Sebenarnya, dalam SMK ada tiga jenis kategori mata pelajaran: normatif, adaptif, dan produktif. Mata pelajaraan yang dalam kategori normatif adalah adalah mata pelajaran yang bersifat teori, sedangkan mata pelajaran produktif adalah mata pelajaran yang bersifat praktik dan berhubungan dengan kejuruan. Selanjutnya, kelas dibagi menjadi dua, yaitu kelas produktif dan kelas normatif. Dalam tiga bulan pertama, peserta didik yang masuk kategori kelas produktif hanya akan memperoleh mata pelajaran produktif, sedangkan mata pelajaran normatif di tiga bulan berikutnya. Begitu pula sebaliknya.

Sayangnya, di akhir semester, peserta didik dituntut untuk menguasai mata pelajaran produktif sama baiknya dengan mata pelajaran normatif. Padahal, kedua jenis mata pelajaran tersebut bukanlah sebuah kesatuan rangkaian di mana yang satu menjelaskan yang lain, di mana mata pelajaran normatif menjadi dasar mata pelajaran produktif atau mata pelajaran produktif menjadi pembuktian mata pelajaran normatif. Keduanya adalah mata pelajaran yang berbeda dan tidak ada kaitannya. Dengan kata lain, peserta didik hanya memperoleh setiap mata pelajaran dalam tiga bulan, baik tiga bulan di awal maupun tiga bulan di akhir, tetapi ketika ujian semesteran mereka harus mampu menjawab dengan baik.

Hal ini menjadi keluhan dan beban tersendiri bagi peserta didik SMKN 3 Salatiga yang menerapkan sistem blocking.

"materinya itu kan jadi padet. Ibaratnya kejar target, kan materinya hanya ditempuh dalam tiga bulan.

"Sebenarnya lima hari itu juga enak. Tapi kalau di SMK (maksudnya SMKN 3 Salatigapen) itu blok-blokan gitu lho. Yang tidak saya suka itu blok-bloknya itu. Materi satu semester itu ditempuh hanya tiga bulan. Padahal materinya itu padat, terus jamnya juga ditambah-tambah. Jadi, otak kan tidak kuat kalau dipaksa-paksa harus berpikir

Pendidikan Agama, Pendidikan Kewarganegaraan, Bahasa Indonesia, Penjas, Olah Raga dan Kesehatan, dan Seni Budaya. Sedangkan mata pelajaran adaptif antara lain Bahasa Inggris, Matematika, IPA, Fisika, Kimia, IPS, dan KKPI. Mata Pelajaran produktif adalah mata pelajaran yang menjadi penunjang utama kemampuan peeserta didik di juurusan yang diambil. Tentunya tiap tpa jurusan meemiliki mata pelajaran produktif yang berbeda antara satu dengan yang lainnya. Akan tetapi, sistem blocking yang berlaku di SMKN 3 Salatiga hanya membagi mata pelajaran ke dalam dua kategori, yakni normatif dan produktif, yang juga berimbas pada pembagian kelas. 
seperti itu. Terus, dulu, kalau enam hari kerja kan materinya diberikan setengah tahun. Satu semseter itu kan setengah tahun. Tapai kalau sekarang materinya tiga bulan. Jadi, mau ndak mau kalau dites itu materi yang tiga bulan itu ya harus ingat. Padahal materi itu, apalagi atematika, wong habis dipelajari itu saja mudah lupa. Apalagi setelah tiga bulan. Jadi itu kan memberatkan sekali" (wawancara dengan Alf, 7/12/2015)

Kelelahan secara fisik juga berupa ngantuk yang dialami oleh peserta didik, baik ketika mengikuti pelajaran di sekolah maupun pelajaran di madrasah.

\begin{abstract}
"Secara umum, anak anak itu capai, lelah, ngantuk. Setelah istirahat kedua dan ketiga, jam dua kurang seperempat sampai jam dua (13.45-14.00 WIB) itu kan istirahat, begitu saya masuk, kata anak-anak, 'Pak ngantuk, Pak. Capai, Pak. Istirahat Pak"' (wawancara dengan JR, 11 Desember 2015). "Capai. Biasanya tidur. Di sekolah itu tidur. Di madrasah ngantuk" (wawancara dengan Erk, 7/12/2015)
\end{abstract}

Hal yang sama juga diakui oleh salah satu peserta FGD peneliti tanya apakah mereka masih bisa aktif mengikuti pembelajaran di madrasah dan juga pondok pesantren sama seperti sebelum program sekolah lima hari diberlakukan.

"Ya bisa, Bu. Tapi ya itu, sambil tidur tidur. Sambil ngantuk-ngantuk. Kadang pas belajar itu bukunya kalau pagi-pagi tiba-tiba sudah ada di bawah gitu lho Bu. Belajar sambil tertidur" (FGD, 7/12/2015).

\section{Dampak Psikologis}

Selain kelelahan fisik, kelelahan secara psikologis juga dialami oleh peserta didik. Hal itu dapat dilihat dari banyaknya jam pelajaran yang harus mereka lahap dalam satu hari. Mereka harus berkutat dengan banyaknya materi yang diberikan. Bahkan, tidak jarang mereka juga harus mengikuti jam tambahan maupun les yang diberikan setelah jam pelajaran. Penjelasan dan uraian tentang kelelahan secara psikologis yang dialami peserta didik dapat dilihat ulang dalam paparan dampak program sekolah lima hari belajar terhadap fisik.

Selain kelelahan secara psikologis, pelaksanaan program sekolah lima hari juga menimbullkan kekhawatiran di kalangan orang tua terhadap perilaku dan kehidupan anaknya. Kekhawatiran itu terjadi ketika anak lebih memilih menghabiskan waktu libur di hari Sabtu main bersama temantemannya daripada berkumpul bersama keluarga. Yang lebih menghawatirkan lagi apabila hal tersebut didukung oleh kebohongan yang dilakukan oleh anak terhadap orang tuanya.

Ada sebuah kasus di mana seorang peserta didik yang juga menjadi santri sebuah pondok pesantren minta ijin pulang di akhir pekan. Akan tetapi, di akhir pekan itu pula orang tua santri justru datang ke pondok pesantren untuk menengok sekaligus memberi "kiriman" kepada anaknya. Alangkah terkejutnya pengurus pondok pesantren karena dalam adminitrasi pondok pesantren santri tersebut tercatat minta ijin pulang dan mendapat ijin pihak pesantren. Tidak kalah terkejutnya orang tua karena mereka tidak mendapati anak sampai di rumah.

"Santri ini kebanyakan luar kota. Ungaran, Ampel Suruh, Boyolali, Ambarawa, Karanggede. Dulu mereka nggak boleh bawa sepedaa. Lambat laun dari pondok pesantren mengijinkan dengan ijin para rama kyai, dengan ijin pengurus, yang sekolah jauh silakan bawa sepeda. Ternyata malah dua hari libur diperuntukkan pulang. Pulang ke rumah. Malah orang tua rumah tanya, cari ke pondok, mau ngirim. Biasanya orang tua itu kan Sabtu Minggu dho ngirim, Bu. Ternyata, lho, dari kepengurusan itu diijinin minta pulang, kok nggak pulang, lho kok nggak sampai rumah? Jadi saling bertanya. Ijin dari anak pulang ke rumah malah saking griya mriki madosi ajaeng ngirimi malah mboten enten" (wawancara dengan Mbc, 7/12/2015)

Hilangnya anak dari pengawasan orang tua dan sekolah menimbulkan kekhawatiran di kalangan orang tua bahwa mereka nantinya akan menjadi lebih nakal.

"Saya justru prihatin dengan anak-anak. Mestinya anak anak itu kalau sudah di luar jam sekolah itu banyak dengan pedidikan di rumah, tapi justru disibukkan dengan pendidikan di sekolah. Sehingga pemikiran saya, semakin anak lepas dari orang tua itu kesempatan untuk menjadi anak yang nakal itu lebih tinggi" (wawancara dengan JR, $11 / 12 / 2015)$. 
Selain itu, orang tua juga merasa khawatir akan pengetahuan dan keahlian keagamaan anak anak mereka sebagai bekal kehidupan di masa mendatang. Kekhawatiran tersebut sangat beralasan karena ketika sekolah menjalankan program lima hari sekolah, tentu saja pulangnya lebih sore daripada sebelumnya imbas dari kepulangan yang lebih terlambat tersebut mengakibatkan mereka tidak lagi bisa mengikuti kegiatan pembelajaran di TPA (Taman Pndidikn Alqur'an) baik karena terlambat maupun memutuskann untuk tidak melanjutkan madrasah sekalian.

\section{"Sebagai orang tua justru saya khawatir dengan anak saya sendiri di rumah. Kenapa? Karena saat ini anak saya sendiri tidak lagi sekolah di TPA tidak lagi sekolah di MI, madrasah. Anak saya itu ketika di rumah tergantung kepada orang tuanya. Le, mandi ke TPA. Le, mandi ke madrasah. Kalau bapaknya itu di sekolah sampai jam 4 seperempat di sekolah sementara TPAnya saja jam setengah 4, MI-nya jam 4, otomatis saya sudah tidak bisa mengarahkan anak saya untuk belajar di madrasah.}

Akibat dari ketidakikutan pendidikan di madrasah ini menjadikan anak memiliki pengetahuan dan kemampuan yang kurang dalam bidang agama. Kalau anak sudah tidak dapat belajar di madrasah diniyah maupun belajar di pondok pesantren, ke mana lagi mereka akan memperoleh pengetahuan agama. Pondok pesantren menjadi basis penanaman pengetahuan keagamaan yang paling mempuni, bahkan lembaga pendidikan keagamaann yang dikelola pemerintah pun tidak banyak dipercayai memiliki kemampuan mencetak generasi yang mengerti agama seperti halnya pondok pesantren.

"Kalau anak anak sudah tidak ikut madrasah dan pondok pesantren, siapa nanti yang akan mengajar mengaji? Anak IAIN? Lha wong banyak kok mahasiswa IAIN yang tidak bisa ngaji. Praktik wudlu saja tidak bisa" (wawancara dengan MC, 7/12/2015)

\section{Dampak Sosiologis}

Salah satu alasan Gubernur Jawa Tengah Ganjar Pranowo mengeluarkan SE Nomor 420/006752/2015 sebagai landasan pelaksanaan sekolah lima hari adalah keinginaannya untuk mempererat hubungan antara anak dengan orang tuanya.
“Saya 'kepingin' sekolah menerapkan lima hari sekolah karena kualitas pertemuan mereka dengan orang tua itu kecil. Saya membayangkan kalau mereka bisa 'weekend' bareng orang tuanya maka komunikasi keduanya berjalan dengan baik".("Gubernur Jateng". www.republika.co.id)

Akan tetapi, tujuan tersebut ternyata tidak berhasil. Waktu yang tersedia untuk anak dan orang tua saling berkomunikasi dan berinteraksi secara intens dan berkualias justru semakin berkurang karena kepulangan anak yang semakin sore. Hari Sabtu yang sebenarnya diharapkan untuk membangun komunikasi dan berinteraksi dengan keluarga juga dihabiskan untuk kegiatan ekstrakurikuler di sekolah. Kalaupun tidak mengikuti kegiatan ekstrakurikuler di sekolah peserta didik juga lebih memilih "main" bersama teman-temannya, bukan berkumpul dan melakukan kegiatan bersama orang tua dan anggota keluarganya.

Bahkan, kekurangharmonisan hubungan orang tua-anak bukan hanya karena anak lebih memilih pergi dan bermain dengan temantemannya, tetapi juga karena berkurangnya waktu yang dimiliki orang tua untuk mendampingi anakanaknya di hari-hari selain Sabtu dan Minggu. Dengan kata lain, ketika sekolah masuk enam hari anak pulang lebih siang sehingga waktu berinteraksi dengan keluarga leih banyak daripada ketika lima hari sekolah. Sementara waktu akhir pekan (SabtuMinggu) yang diharapkan menjadi pengganti waktu kebersamaan yang hilang dari Senin sampai Jum'at ternyata juga tidak didapatkan.

Kebersamaan yang dijalin orang tua dan anak dapat berupa kegiatan-kegiatan yang bersifat refreshing maupun juga kepedulian orang tua menemani anak belajar. Akan tetapi, akibat pemberlakukan sekolah lima hari maka anak sudah dalam keadaan lelah setelah pulang sekolah. Apalagi, apabila orang tua juga merupakan orang tua yang juga bekerja lima hari, bahkan kalaupun orang tua berstatus sebagai guru sekolah, rasa capai yang dialami kedua pihak menjadi sebab utama hilangnya interaksi orang tua-anak dalam pendampingan belajar di rumah. Hal inilah yang dirasakan oleh JR, salah satu guru satuan pendidikan yang mereapkan lima hari belajar di sekolah.

"Dulu, ketika masih enam hari kerja, anak saya kalau mau tes saya masih bisa membelajari anak saya sendiri. Di rumah. Tetapi sekarang setelah lima hari kerja, saya 
sudah capai. Begitu pulang saya membelajari anak tidak mungkin, akhirnya anak saya biarkan sampai sore, bahkan sampai malam pun, mau membelajari baru seperempat jam pun sayanya yang sudah tidur, gara-gara kecapaian di sekolah" (wawancara dengan JR, $11 / 12 / 2015)$

\section{Dampak Ekonomi}

Sekilas, pelaksanaan sekolah lima hari belajar tidak berdampak terhadap bidang ekonomi. Akan tetapi, dalam beberapa wawancara yang peneliti lakukan, baik kepada orang tua maupun kepada peserta didik satuan pendidikan pelaksana sekolah lima hari belajar, peneliti menemukan terjadi peningkatan jumlah uang yang harus dikeluarkan karena kebijakan tersebut. Dalam bahasa salah satu orang tua, sekolah lima hari lebih boros daripada sekolah enam hari.

"Katanya kalau lima hari biar ngirit. Malah boros, Bu. Anak saya waktu masuk enam hari jajannya cuma lima ribu, setelah lima hari naik sepuluh ribu. Nggak tega to $\mathrm{Bu}$, pulangnya lebih sore" (wawancara dengan MC, 7/12/2015)

Hal yang sama juga diakui oleh dua orang peserta didik SMAN 1 Salatiga yang mengalami kenaikan jumlah uang saku setelah sekolah memberlakukan lima hari belajar. Seperti yang diceritakan oleh AO, seorang siswi kelas XII SMAN 1 Salatiga. Ketika sekolah masih masuk enam hari uang jajannya sebesar lima ribu rupiah. Tetapi setelah sekolah masuk lima hari, uang sakunya menjadi tujuh ribu rupiah. Kenaikan tersebut diakui oleh AO karena perubahan hari sekolah dari enam hari menjadi lima hari.

Hal serupa juga terjadi pada AM. Ketika sekolah masih masuk enam hari, uang jajan AM sebesar sepuluh hingga lima belas ribu. Akan tetapi, setelah sekolah masuk lima hari, uang jajannya menjadi seratus ribu seminggu. Artinya, dalam sehari uang jajan AM naik menjadi dua puluh ribu rupiah. (wawancara dengan AO dan AM, 11 Desember 2015).

Selain berdampak pada jumlah uang saku, pelaksanaan sekolah lima hari kerja juga berdampak secara ekonomi dalam hal bantuan anak terhadap orang tuanya. Tidak semua peserta didik yang sekolah lima hari di Kota Salatiga berasal dari keluarga berada. Banyak dari mereka yang berasal dari keluarga kurang mampu yang bekerja sebagai penjual gorengan maupun penjual koran. Sepulang sekolah, mereka membantu keluarganya dengan ikut terlibat dalam penjualan tersebut. Akan tetapi, setelah sekolah masuk lima hari, pulang mereka lebih sore. Akibatnya, waktu yang mereka berikan untuk membantu kegiatan ekonomi juga berkurang. Sementara itu, hari Sabtu yang seharusnya libur dan dapat digunakan untuk membantu keluarga ke pasar, kenyataannya tidaklah libur karena diisi dengan kegiatan ekstrakurikuler.

\section{PENUTUP}

Dari uraian di atas kita dapat mengetahui bahwa pelaksanaaan PS5H di Kota Salatiga yang lebih mendasarkan diri pada Surat Edaran Gubernur Jawa Tengah Nomor 420/006752/2015 yang kemudian ditindaklanjuti dengan Surat Keputusan Kepala Pendidikan Provinsi Jawa Tengah Nomor 420/03737 dan Surat Kepala Dinas Pendidikan Provinsi Jawa Tengah Nomor 420/03738. Sayangnya, walaupun SK Kepala Dinas Pendidikan Provinsi Jawa Tengah Nomor 420/03737 memilihkan model 11 dalam pelaksanaan program sekolah lima hari, tetapi pelaksanaan di lapangan tidak demikian. Hal itu dapat dilihat dalam Surat Keputusan Kepala Dinas Pendidikan Provinsi Jawa Tengah Nomor 420/03737 Bab 1 Pasal 1 Ayat 6. Dalam pasal tersebut diatur bahwa semua kegiatan harus didistribusikan pada hari Senin hingga Jum'at. Akan tetapi, dalam pelaksanannya, hari Sabtu masih digunakan untuk menyelenggarakan kegiatan.

Perubahan hari pembelajaran di sekolah ini yang semula dilaksanakan selama enam hari dalam seminggu menjadi lima hari ini tentu saja berimbas terhadap pelaksanaan pendidikan di lembaga pendidikan nonformal yang secara umum menyelenggarakan pendidikan selepas pendidikan formal. Secara proses, ritme, dan kegiatan pelaksanaan pendidikan keagamaan yang sebagian besar tertumpu pada TPA, madrasah diniyyah, dan pondok, PS5H tidak terlihat nyata. Hal itu pihak lembaga pendidikan nonformal melakukan beberapa perubahan kebijakan untuk penyesuaian, seperti perubahan jam masuk maupun beben tugas yang diberikan kepada para pembelajarnya.

Berbeda dengan kondisi tersebut, justru dampak pelaskanaan PS5H dapat terlihat langsung dan nyata terhadap para peserta didik di lembaga pendidikan nonformal, baik secara fisik, psikis, ekonomi, dan sosiologis. Bahkan, secara sosiologis, program yang salah satu tujuannya untuk mendekatkan hubungan orang tua dan anak ini 
justru dalam kenyataanya tidak tercapai karena anak lebih memilih main bersama teman-temannya maupun masih sibuk ke sekolah untuk mengikuti kegiatan ekstrakurikuler. Dengan demikian, program sekolah lima hari dalam praktiknya hampir tidak beda dengan program sekolah enam hari.

\section{UCAPAN TERIMA KASIH}

Tulisan ini dapat terwujud karena peran serta dan bantuan para informan di lapangan yang telah bersedia meluangkan waktu berbincang-bincang dengan peneliti di sela-sela kesibukan mereka. Mereka adalah guru dan beberapa siswa SMAN 1 Salatiga, siswa dan siswi SMAN 2 dan SMKN 3 Salatiga, pengurus dan santriwan santriwati Sunan Giri, serta orang tua siswa yang bersedia menceritakan perbedaan ritme anaknya sebelum dan setelah PS5H. Selain itu, bantuan dari pegawai Dinas Pendidikan dan Pemuda Olah Raga serta data yang diberikan oleh pengurus MUI Kota Salatiga juga sangat berharga untuk melengkapi data penelitian ini. Kepada mereka penulis mengucapkan terima kasih.

\section{DAFTAR PUSTAKA}

"Gubernur Jateng Ingin Seluruh Sekolah Terapkan Lima Hari Belajar". www.republika.co.id

Agusta, Ivanovich. 2003. "Teknik Pengumpulan dan Analisis Data Kualitatif". Makalah disampaikan dalam Pelatihan Metode Kualitatif di Pusat Penelitian Sosial Litbang Pertanian pada 27 Februari 2003 di Bogor

Akhiruddin, KM. 2015. "Lembaga Pendidikan Islam Nusantara”. Jurnal Tarbiya Vol. 1 Nomor 1 Tahun 2015. Halaman 195-219

Andriani, Asna. 2016. "Munculnya Lembaga Pendidikan Islam". Falasifa Vol. 7 Nomor 2 September 2016. Halaman 123-136.

Andrianingsih. 2016. "Full Day School: Model Allternatif Pembelajaran Karakter di Sekolah". Prosiding Seminar Nasional Repositioning Full Day School Pendidikan Formal, Nonformal, dan Informal.Malang: Universitas negeri Maang

Bangsa Online. 16 Juni 2017. "DPRD dan Pesantren Jombang Kompak Tolak FDS Mendikbud". https://www.bangsaonline.com/ berita/34968/dprd-dan-pesantren-jombangkompak-tolak-fds-mendikbud, diakses 22 Nopember 2017.

Cryan, John R., Robert Sheehan, Jane Wiechel, dan Irene G. Bandy-Hedden. 1992. "Success
Outcomes of Full-day Kindergarten: More Positive Behavior and Increased Achievement in the years after". Early Childhood Research Quarterly. Vo. 7 Issue 2. June 1992. Pages 187203

Detiknews. 7 Agustus 2017. "Ribuan Santri Aksi Tolak Program Lima Hari Sekolah". https://news.detik.com/berita-jawatengah/d-3588820/ribuan-santri-banyumasaksi-tolak-program-lima-hari-sekolah, diakses 21 Nopember 2017.

Duta. 7 Juli 2017. “Tak Direspon Pemerintah, NU dan 13 Ormas Kembali Tolak FDS". https:// duta.co/tak-direspon-pemerintah-nu-dan13-ormas-islam-kembali-tolak-fds/, diakses pada 22 Nopember 2017.

Gullo, Dominic F. 2006. "The Long-Term Educational Effects of Half-Day vs. Full-Day Kindergarten." Early Childhood Development and Care. Volume 160, Issue 1, Tahun 2000, published online 07 Juli 2006, pages 17-24

Hawi, Akmal, "Sistem Full-Day School di Sekolah Dasar Islam terpadu (SDIT) Studi Kasus di Izzuddin Palembang." Istinbath No. 16 Tahun XIV/Juni/2015. Halaman 71-87.

Hidayat, Heri. 2013. “Teologi Lembaga Pendidikan Islam”. Ijtimaiyya Vol. 6 Nomor 2 . halaman 115-138.

Jawa Pos, 30 Agustus 2017. "Belasan Ribu Warga NU Aksi Tolak FDS”. http://radarsemarang. com/2017/08/30/belasan-ribu-warga-nuaksi-tolak-fds/, diakses 22 Nopember 2017.

Kanwil Kemenag Provinsi Jawa Tengah. 2015. "Kebijakan Sekolah 5 Hari" Sejahtera Edisi 6 Tahun 1 Juni 2015. Halaman 5-7

Kastanja, Jubelina Inosensia. 2013. "Strategi Bersaing Sekolah Kristen Lentera Ambarawa”. Tesis S2 Program Pascasarjana Magister Manajemen Pendidikan Universitas Kristen Satya Wacana Salatiga

Kompas.com, 18 Agustus 2017. "Tolak 'Full Day School, Ribuan Warga NU Semarang Usung 2 Keranda”. http://regional.kompas.com/ $\mathrm{read} / 2017 / 08 / 18 / 16302671 /$ tolak-full-dayschool-ribuan-warga-nu-semarang-usung-2keranda, diakses 22 Nopember 2017.

KR Jogja. 16 Juni 2017. "Datangi Bupati, Kader NU Sleman Tolak FDS”. http://krjogja.com/ web/news/read/41100/Datangi_Bupati_ Kader_NU_Sleman_Tolak_FDS, diakses 22 Nopember 2017.

Liputan 6.com, 28 Agustus 2017. "Giliran Ribuan 
Warga NU Batang Tolak Full Day School”. http://regional.liputan6.com/read/3074508/ giliran-ribuan-warga-nu-batang-tolak-fullday-school, diakses 22 Nopember 2017.

Nastiti, Tika Asih. "Implementasi Program Full Day School dalam Pembentukan Karakter Anak di SD Islam Terpadu Taruna Teladan Delanggu Tahun 2015/2016". Skripsi Pendidikan Sosiologi Antropologi Fakultas Keguruan dan Ilmu Pendidikan

Novalina, Siagian. 2013. "Pengaruh Penerapan Program Sekolah Lima Hari (PS5H) terhadap Prestasi Belajar Ekonomi Siswa Kelas X SMAN 1 Girsang Sipangan Bolon Tahun 2012/2013. Skripsi S1 Pendidikan Tata Niaga Universitas Negeri Medan.

Noya, Nevi Olivia. 2014. "Strategi Bersaing Sekolah Menengah Atas Kristen 1 Salatiga”. Tesis S2 Program Pascasarjana Magister Manajemen Pendidikan Universitas Kristen Satya Wacana Salatiga.

Oktaviani, Tri. 2017. "Efektivitas Full Day School dalam Pembentukan Akhlak Siswa di SD Integral Hidayatullah Salatiga". Skripsi Fakultas Tarbiyah dan Keguruan IAIN Salatiga.

Peraturan Menteri Pendidikan dan Kebudayaan Nomor 23 Tahun 2017 tentang Hari Sekolah.

Pramono. Sidik. 2017. "Strategi Public Relations Kemendikbud dalam Sosialisasi Kebijakan Full Day School untuk Memperkuat Pendidikan Karakter Siswa". Prosiding Komunikasi Publik dan Dinamika Masyarakat Lokal. Universitas Negeri Lampung

Rachmat, Nur. 2015. "Kultur dan Sekolah Lima Hari”. Suara Merdeka, 1 Agustus 2015

Radar Bangka. "NU Tolak Sekolah Full Day". 16 Juni 2017, halaman 4

Radar Kudus. 31 Agustus 2017."Sepuluh Ribu Massa Long March Tolak FDS”. https://www.jawapos. com/radarkudus/read/2017/08/31/10889/ sepuluh-ribu-massa-long-march-tolak-fds, diakses 22 Nopember 2017.

Rilis. 24 Agustus 2017. "Ribuan Nahdliyin Indramayu Tolak FDS”. http://rilis.id/ribuannahdliyin-indramayu-tolak-fds.html, diakses 22 Nopember 2017.

Roshayanti, Fenny, dkk. 2015. "Respon Masyarakat terkait Kebijakan Program Sekolah Lima Hari (PS5H) di Provinsi Jawa Tengah". Makalah dalam Seminar Nasional Hasil Penelitian (SNHP-V) Lembaga Penelitian dan Pengabdian Kepada Masyarakat Universitas
PGRI Semarang, Semarang, 21 Nopember 2015.

Seftiana. 2017. "Analisis Penerapan Kebijakan Penerapan Full Day School terhadap Hasil Belajar Siswa Kelas X di MAN 1 Surakarta”. Skripsi. Fakultas Keguruan dan Ilmu Pendidikan Universitas Muhammadiyah Surakarta.

Siregar, Lis Yulianti Syafrida. 2017. "Full Day School Berbasis Alqur'an (Suatu Tinjauan Psikologi Pendidikan Islam)". Prosiding Seminar Nasional Pendidikan 2017. Program Studi Manajemen Pendidikan Pascasarjana Universitas Negeri Maang bekerja sama dengan Asosiasi Prodi Manajemen/ Administrasi Pendidikan Indonesia.

Sitepu, B.P. 2002. "Model Program Sekolah Lima Hari". Jurnal Pendidikan Penabur Nomor 01/ Th.I/Maret 2002. Halaman 43-63.

- 2004. "Program Sekolah Lima Hari: Evaluasi Formatif". Jurnal Pendidikan Penabur No.03/ Th. III/Desember 2004. Halaman 78-88.

Suara Nahdhatul Ulama, 23 agustus 2017. "20 Ribu Warga Bakal Padati Kota Solo untuk Tolak FDS". http://www.nu.or.id/post/ $\mathrm{read} / 80665 / 20$-ribu-warga-bakal-padatikota-solo-untuk-tolak-fds, dakses 22 Nopember 2017.

Suara NTB. 17 Agustus 2017. “Terima Demo Ratusan Santri Tolak FDS, Ini Permintaan TGB kepada Pemerintah Pusat". http://www. suarantb.com/news/2017/08/17/243731/ Terima.Demo.Ratusan.Santri.Tolak.FDS,Ini. Permintaan.TGB.kepada.Pemerintah.Pusat, diakses 22 Nopember 2017.

Sumartyarini, Tri Umi. 2015. "Ancaman Sekolah Lima Hari”. Suara Merdeka, 7 Agustus 2015.

Surabaya Pagi, "NU Tolak FDS", 24 Juli 2017. Halaman 3

Surat Keputusan Kepala Dinas Pendidikan Provinsi Jawa tengah Noor 420/03737 tentang Suplemen Pedoman Penyususnan Kalender Pendidikan 5 (Lima) Hari per Minggu Tahun Pelajaran 2015/2016

Tribune Jateng, 24 Agustus 2017. "PCNU Solo Raya Gelar Aksi Demo Tolak FDS”. Tribune Jateng, 24 Agustus 2017. http://jateng.tribunnews. com/2017/08/24/pcnu-solo-raya-gelar-aksidemo-tolak-fds, diakses 22 Nopember 2017.

Warta Bromo. 20 Agustus 2017. "Tolak FDS, Santri Pasang Spanduk di Seluruh Jalan Protokol Wilayah Pasuruan". http://www.wartabromo. 
com/2017/08/20/tolak-fds-santri-pasangspanduk-di-seluruh-jalan-protokol-wilayahpasuruan/, diakses 22 Nopember 2017.

Winurini, Sulis. 2016. "Wacana Penerapan Full Day School Untuk Siswa SD dan SMP”. Majalah Info Singkat Kesejahteraan Sosial. Vol. VIII Nomor 15/I/P3DI/Agustus/2016. Pusat
Penelitian Badan Keahlian DPR RI

Zvoch, Keith, Ralp E. Reynolds, dan Robert P. Parker. 2008. "Full-day Kindergarten and Student literacy Growth: Does a lengthened School Day Make a Difference?" Early Childhood Quarterly. 1st Quarter, pages 94-107 